\title{
Comparison of Public Sector Finance measures from the National Accounts and Whole of Government Accounts
}

Authors:

Chris Daffin (Office for National Statistics)

David Hobbs (Office for National Statistics)

\section{Introduction}

The Whole of Government Accounts (WGA) are a consolidated set of financial statements for the whole of the Government of the United Kingdom of Great Britain and Northern Ireland. They include central government, devolved administrations, local authorities, NHS and public corporations. The accounts will enhance the coverage, quality and transparency of the information publicly available for monitoring and analysing the sustainability of the public finances providing additional information of items such as provisions and contingent assets and liabilities to complement existing National Accounts (NA) measures.

The first set of accounts covering the financial year 2009/10 will be published by HM Treasury later in 2011.

This article precedes the publication of the first WGA data and therefore does not itself present any new statistical information about the public finances. Its purpose is to describe the main conceptual differences between NA and WGA and to highlight key areas that are the cause of significant variations between measures compiled from the two systems.

\section{Key conceptual differences between NA and WGA}

ONS produces the National Accounts - a coherent, consistent and integrated set of macro-economic accounts, balance sheets and tables for the UK - according to internationally agreed and comparable accounting frameworks, including the European System of Accounts (ESA95) based on the System of National Accounts $\left(\right.$ SNA $\left.1993^{1}\right)$. Additional interpretation guidance is provided in various manuals published by Eurostat - the European statistical agency - such as in the ESA95 Manual on Government Deficit and Debt (MGDD) ${ }^{2}$. The current ESA rules will be replaced by a revised edition ('ESA2010') in line with the updated SNA2008 applicable in full from 2014.

The WGA will be prepared by HM Treasury according to EU adopted International Financial Reporting Standards (IFRS) as interpreted and/or adapted for the public sector context in accordance with advice from the independent Financial Reporting Advisory Board (FRAB) ${ }^{3}$.

The WGA/IFRS and ESA95 systems of accounting have some fundamental similarities. Both systems apply the internationally recognised concept of accruals accounting and they each present balance sheets, income and expenditure statements and explanations of other changes in balance sheet positions, albeit in different formats. 
However, a number of differences exist between the WGA/IFRS and ESA95 systems, partly as a consequence of the fact that the two systems have reached their accounting solutions independently and partly as these are different systems designed to suit different purposes. Some of the consequent differences are listed below:

- Scope and articulation - the NA provide, as far as possible, a fully articulated picture of economies. Consequently, any transaction or balance sheet position must balance out across the economy's sectors or across different economies. It is not acceptable, for example, for an asset not to be balanced by a matching liability within the NA system. This makes the NA framework suitable for economic analysis and formulation of macroeconomic policy. In contrast, IFRS is primarily designed to serve business' accounting needs. Accordingly, it focuses on the accounts of the single entity or corporate group and does not necessarily require, for example, an asset recognised by one business entity to be mirrored by an equal and opposite liability in another entity's accounts.

- Data sources - the WGA contain data collected on an IFRS basis for institutions classified to the public sector, except as described in the account. The data are then adjusted to eliminate intra-group transactions and balances. For central government NA data are captured from a variety of sources, including HM Treasury's COINS system, administrative data from HMRC and the Government's cash management systems, which should, in the main, be consistent with WGA. For local government the NA data sources are statistical surveys carried out by CLG and the devolved administrations. The NA source for public corporations is the corporations' own accounts adjusted for NA concepts and definitions. The other main difference in source data is for the non-financial balance sheet and depreciation, where the NA use a model, see the section on the Perpetual Inventory Method (PIM) below.

- Accruals and timing - the accruals concepts for NA and WGA are for the most part similar. However, there are some differences at a detailed level, for example in the accrual methodology for some taxes and interest payments, including those on student loans. Also NA data are produced in-year, to tighter timescales and with the aim of producing consistent time-series and therefore have a restrictive policy as to when revisions can be included. Under IFRS, WGA accruals are assessed and recognised at the end of each reporting period and will change from year to year

- Sectoral coverage and consolidation - a key difference in coverage is the treatment of the assets of the public sector banks. In the NA, Lloyds Banking Group, the Royal Bank of Scotland, Bradford and Bingley and Northern Rock (public sector banks) are considered part of the public sector but are scored in the financial corporations sector ${ }^{a}$. The public sector banks are within the WGA boundary. They are included as investments but have not been fully consolidated.

Unlike WGA the NA consolidate transactions within the central government, local government and public corporation sectors. Also WGA consolidate transactions at an individual level while NA take a broader view and eliminate

a It should be noted that PSF scores these banks within the public sector but also acknowledges the temporary effect of some of the financial sector interventions and therefore also publishes measures of deficit and debt that exclude the public sector banks, see the article 'Public Sector Finances excluding Financial Sector Interventions' by Jim O'Donoghue (2010) www.statistics.gov.uk/cci/article. asp?ID=2380\&Pos=1\&ColRank=1\&Rank=1. 
at the data source level, for example using the total reported from central government sources for central government to local government grants.

- Liability recognition - in general, WGA recognises a wider range of liabilities than NA. Examples include public service pensions, Private Finance Initiative commitments and provisions.

- Contingent assets and liabilities - WGA will provide detailed information on contingent assets and liabilities although, under IFRS, they are not recognised as assets or liabilities on the balance sheet. The NA system does not recognise contingent liabilities, although some data are available in supplementary information published by ONS, see the next steps section below.

\section{Differences in NA and WGA measures of debt and deficit}

The following sections highlight the main conceptual differences that account for the largest divergence between key fiscal aggregates based on NA and their nearest WGA equivalent. The two key fiscal aggregates are Public Sector Net Debt and Surplus on Current Budget because these are used as the basis for the Government's fiscal mandate and supplementary target for debt. The list results from an initial study by ONS and HM Treasury comparing detailed transactions underlying these fiscal aggregates to the emerging WGA data.

\section{Public Sector Net Debt}

Public sector net debt (PSND) is an important measure of public sector indebtedness and the basis of the Government's fiscal policy target for debt to be falling in 2015/16. It is defined as financial liabilities less liquid assets (mainly consisting of foreign exchange reserves and bank deposits) with both scored at face value. The netting off of liquid assets results in a narrow definition of net debt. In estimating PSND, public sector holdings of public sector debt are consolidated out.

The closest equivalent to PSND in WGA is the net balance sheet position; sometimes called Taxpayers' Equity. This is a broader meaure of the public sector's balance sheet position, including a wider range of both assets and liabilities. The relationship is as follows:

WGA net balance sheet position

less

Public service pension liabilities

Provisions

Differences in treatment of tangible and intangible fixed assets

Working capital

Illiquid financial assets

Other smaller differences

equals

Public Sector Finances net debt (excluding financial interventions)

Public sector net debt is an aggregate that includes financial liabilities, apart from payables and only nets off liquid financial assets, whereas the WGA balance is an accrued balance sheet, including payables and receivables, fixed assets and all 
financial assets. The areas that account for the largest divergence between PSND and the WGA net balance sheet position are discussed below.

\section{Public service pensions}

The treatment of pensions in the NA is a complex issue. When considering the public sector, we need to look at two aspects; pensions paid by the state to individuals and pensions paid by government as employers. The former consist of the Basic State Pension and the State Second Pension (including the former State Earnings Related Pension Scheme). These are treated in a similar way in both NA and WGA. The state pension becomes payable to individuals as it falls due and consequently WGA does not have a provision for State pension liabilities (or any other State benefits). NA does not account for future expenditure, so does not record these either.

However, pensions paid by government as employers, such as the civil service pension scheme, are treated differently in WGA. Accrued liabilities or future obligations in respect of past events (i.e. an employee completing a period of service) are part of the WGA. They are not currently included in the NA and so do not affect the NA measure of debt. ESA2010 will change how accrued pension liabilities are recorded in the NA. Pension liabilities accrued to date will be recorded in a supplementary table and therefore will not initially impact on the NA measures of deficit and debt.

\section{Provisions}

A provision is an assessment of future expenditure arising from past events. It is scored as a liability of uncertain timing and/or amount and is recognised in WGA. Such public sector provisions include, for example, those relating to; decommissioning nuclear plant and facilities, industry related diseases from previously nationalised industries, claims for alleged clinical negligence and provisions for public sector early departure costs. The WGA records provisions in the balance sheet and changes in these provisions impact on current expenditure. The NA do not recognise provisions as liabilities but do record any associated expenditure in the period in which it actually occurs.

\section{Private Finance Initiatives (PFI)}

$\mathrm{PFI}$ contracts involve private sector bodies in producing public sector infrastructure and/or services. Judgements must be made on which balance sheet (public or private) the associated assets and finance lease liabilities should be included. In making such judgements, the WGA follows IFRS (specifically IFRIC12) accounting guidance, which is based largely on the issue of control of the contract. NA and PSF follow ESA95 rules that focus on the transfer of risks and rewards. Under the different treatments, the WGA balance sheet will recognise significantly more PFI (tangible and intangible) assets and financial liabilities on the balance sheet than PSND as defined by NA.

\section{$\underline{\text { Tangible and intangible assets }}$}

PSND does not include tangible and intangible assets unlike the equivalent WGA measure, because it measures only financial liabilities and liquid assets. In NA, net additions of fixed assets are treated as capital spending and contribute to Public Sector Net Borrowing (PSNB). There are conceptual differences in the estimates of fixed assets between NA and WGA, see the section on the Perpetual Inventory Method (PIM) below. 


\section{Working capital and illiquid assets}

PSND is calculated net of certain assets that are considered to be liquid, but does not take account of other illiquid and other assets within working capital such as debtors and creditors. However, PSND does include cash and short-term deposits. For more details see O'Donoghue's (2008) ${ }^{4}$ article on the definition of PSND.

\section{Public Sector Current Budget Deficit/Surplus}

Public sector current budget deficit/surplus (PSCB) is the measure which forms the basis of the Government's fiscal mandate. It is the difference in the accounting period between accrued current revenue and expenditure as defined by the NA. The closest WGA equivalent to the PSCB is the net deficit/surplus for the year. The relationship is as follows:

WGA net deficit/surplus for the year less

Net interest on public service pension scheme liabilities Impairment charges

Capital grants

Depreciation differences between WGA and NA

Movements on provisions

Other smaller differences

Equals

Public Sector Finances current deficit/surplus (excluding financial interventions)

The difference between NA and WGA measures of net deficit/surplus is mainly due to the treatment of pensions (interest on pension assets and liabilities), impairment charges, capital grants and movements on provisions. The conceptual differences for each area are discussed further below.

\section{Public service pensions and provisions}

As explained above, future liabilities for public service pensions and provisions are not recognised in NA. Movements in these liabilities are recognised in the WGA net result for the year but not in PSCB based on the NA. For unfunded pensions, NA include only the cash payments and receipts associated with pensions, but do not take account of movements in future pension liabilities. WGA is prepared on an accruals basis and recognises an estimate of the value of the liability associated with accrued pension rights. To comply with accounting standards, interest on pension scheme liabilities (and returns on assets for funded schemes) are charged in year. Net interest on public sector pensions is therefore included in WGA but not in the NA. Similarly, with provisions NA does not recognise the in-year movements in their value as current expenditure but does recognise any associated expenditure in the accounting period in which it actually occurs.

$\underline{\text { Impairments and depreciation }}$

Impairments are charges or expenses that are made to recognise the amount by which the carrying value of an asset exceeds its recoverable amount. The concept of impairment differs in WGA from NA and the treatment therefore also differs. In NA most impairments are excluded from the measure of deficit. The ones that are included are those caused by normal obsolescence and normal accidental damage 
that are included in the NA measure of depreciation. Also the PSCB based on NA currently sources depreciation of non-financial assets from a model rather than from accounting data, see the section on the Perpetual Inventory Method (PIM) below. In WGA, impairment can arise from a number of sources other than foreseen physical deterioration of the asset, including unforeseen physical deterioration and a significant fall in the market value of the asset or technological changes.

\section{Capital Grants,}

Capital grants are treated as part of the net deficit/surplus for the year in WGA (equivalent to current expenditure in NA), as they do not result in the creation of an asset directly for the public sector itself. However, these are treated as capital expenditure in NA as they do finance the creation of an asset. Capital grants are included within the national accounts as a capital charge and therefore not included within PSCB but are included in PSNB.

\section{Comparing the Perpetual Inventory Method and the Whole of Government Accounts for depreciation}

As well as reconciling NA and WGA measures of debt and deficit/surplus ONS and HMT have been looking at the use of WGA data on central government capital consumption and how this may be used to improve on the current Perpetual Inventory Method (PIM) used in NA for the derivation of net capital stock, specifically for use in estimating depreciation. The use of this administrative data rather than the PIM was originally proposed in the Atkinson review $(2005)^{5}$, see recommendation 5.6.

An accompanying article has been published by ONS that provides more detail on the work; see Craig McLaren $(2011)^{6}$. The article provides an overview of the PIM used by ONS and lists the key conceptual and theoretical differences between PIM and WGA. The article concludes that using WGA will be an overall improvement to the PIM estimates for the central government sector of capital consumption (depreciation), after adjusting for these differences. The article precedes publication of the first WGA data and so does not include any WGA results but emerging WGA data were used in comparing the two methods.

\section{Conclusion and next steps}

ONS publishes a range of statistical information pertinent to the public finances and fiscal sustainability. This includes the public sector transactions and balance sheet positions presented within the annual NA 'Blue Book', the monthly Public Sector Finances (PSF) statistical bulletin ${ }^{8}$ and the biannual Government Deficit and Debt under the Maastricht Treaty statistical bulletin ${ }^{9}$. The availability of WGA allows ONS to review some of its data sources for these publications. Two areas that WGA will impact are the supply of public corporation data and estimates of the depreciation of central government assets.

Early results from the comparison of public corporation data show that the majority of the main aggregates are similar. However, investigation work continues and where the results are comparable ONS intends to use the data from the WGA in NA. Using WGA data reduces the burden on respondents and is a more efficient way of compiling the results. ONS intends to do this as soon as is reasonably possible. 
ONS intends to use WGA data in its estimation of the depreciation of central government assets. Incorporating a new measure of central government asset depreciation in the NA is complex and the earliest that this can be done will be for the Blue Book publication in 2012. ONS will also use the WGA depreciation data in its estimates of surplus on current budget in the monthly Public Sector Finances (PSF) statistical bulletin. The less restrictive revisions policy for PSF means that changes can be made earlier than for the NA and ONS intends to incorporate WGA depreciation data as soon as is reasonably possible ahead of the 2012 Blue Book.

ONS will continue to publish supplementary information through articles such as the 'Wider Measures of Public Sector Debt' ${ }^{\text {'0 }}$, for which the next update is due in the autumn of 2011, and the Pensions Trends publication ${ }^{11}$. ONS will be producing detailed information on public sector pension obligations in line with ESA2010. The first provisional results will be available in mid 2012. Together, these publications will compliment the NA and provide a broader range of information about the public sector balance sheet. In addition, the Office for Budget Responsibility will be publishing on 13 July 2011 the first of their annual Fiscal Sustainability Reports, which will include an assessment of the fiscal sustainability implications of different methods of looking at the public sector finances.

HM Treasury will publish the first set of WGA covering the financial year 2009/10 later in 2011. More complete explanations of the differences between figures produced under the NA and WGA systems will be forthcoming as part of the detailed reconciliation statements that will accompany the publication of WGA.

\section{References}

$1 \quad$ United Nations Statistics Division: National Accounts.

http://unstats.un.org/unsd/nationalaccount/

2 Eurostat: Manual on Government Deficit and Debt. http://epp.eurostat.ec.europa.eu/portal/page/portal/product details/publication?p product code=KS -RA-09-017

3 HM Treasury: Financial Reporting Advisory Board. www.hm-treasury.gov.uk/psr frab index.htm

4 O'Donoghue J (2008) 'Inclusion of Bank of England and Northern Rock in Public Sector Finance Statistics', Office for National Statistics.

www.statistics.gov.uk/cci/article.asp?ID=2047\&Pos=1\&ColRank=1\&Rank=1

5 Atkinson Review (2005) 'Final report Measurement of Government Output and Productivity for the National Accounts', Office for National Statistics. www.statistics.gov.uk/about/data/methodology/specific/publicSector/atkinson/final report.asp

6 McLaren G H, Saunders I, Zammit C (June 2011) 'Comparing the Perpetual Inventory Method and the Whole of Government Accounts for depreciation', Office for National Statistics. www.statistics.gov.uk/StatBase/Product.asp?vlnk=10730\&Pos=1\&ColRank=2\&Rank=816

7 Office for National Statistics: United Kingdom National Accounts - The Blue Book. www.statistics.gov.uk/statbase/product.asp?vlnk=1143

8 Office for National Statistics: Public Sector Finances. www.statistics.gov.uk/statbase/Product.asp?vlnk $=805$

9 Office for National Statistics: Government deficit and debt under the Maastricht Treaty www.statistics.gov.uk/Statbase/Product.asp?vlnk=3766

10 Hobbs D (2010) 'Wider Measures of Public Sector Debt: An Update', Office for National Statistics. www.statistics.gov.uk/cci/article.asp?id=2589

11 Office for National Statistics: Pension Trends www.statistics.gov.uk/pensiontrends/ 